\title{
The fallacy of Van Helmont's tree
}

\section{Peace}

within a

\section{password}

Of the zillion appendages that attire a doctor (flapping tourniquets, plastic ID badges, and battered stethoscopes), I believe passwords warrant some further attention. It's these little wonders which, in the frantic whirlwind of medicine, afford the doctor something unique: one, access to computer systems; two, something more, much more.

Passwords offer escapism - one split second of detachment from the world of smelly dinners and high pitched bleeps seven/eight/nine letters entirely of your choosing, whose significance is known to you alone. These precious letters could be personal, calling to mind a lost relative, a lover, a favourite pet, a (backed) winning race-horse, an exotic holiday, a childhood haunt, a word of prayer. Or, for the academics among you, a mathematical formula, a chemical element, a word in translation that helps you keep up your foreign language skills. Maybe they're provocative letters, a nickname reworking of your least favourite consultant or a memorable expletive.

This may be pushing the boat out but l've one last levy of praise to add to the theme. Even your logon can be exciting a fancy rejuggling of your initials and surname can concoct something exotic out of something extraordinarily simple. I've actually become quite fond of my 'elinga'. Its got a ring to it.

And so I propose this. Next time you log onto pathology to see whether X's renal function has improved or onto radiology to see whether that bizarre CT scan of $Y$ has at last been reported, afford yourself a treat. Take a deep breath and let your mind actually relish the seven/eight/nine letters that trickle out from your fingertips.

\section{Elizabeth Ingall}

DOI: 10.3399/bjgp10X501985
A campaign sponsored by the "happiness tsar' Richard Layard and backed by the entire medical, psychiatric, and social policy establishment is recommending 'evidence-based' psychological therapies for up to one-third of the population. ${ }^{1}$ But is their evidence sound?

According to Professor Layard, the scale of Britain's mental health problem is 'massive': one in three families are affected. ${ }^{2}$ He believes that 'one in ten' children and 'one in six' adults are suffering from a 'diagnosable problem requiring professional help'. It is immediately apparent that these rates of diagnosis can only be achieved by the dramatic inflation of familiar diagnostic categories and the expansion of the scope of psychiatric labelling from a small minority of sufferers to a substantial proportion of the population. The claim that these vast numbers of people with mental illness are 'treatable' arises by extrapolation from the results of small academic studies to vast clinical populations. If diagnosis lacks determinacy, so also does treatment - it is by no means clear what elements of the 'talking' cures favoured by Lord Layard and his supporters produce the outcomes they observe (and quantify with dubious empirical validity).

It appears that Lord Layard has fallen victim to the fallacy of Van Helmont's tree, named in honour of the 17th century Flemish chemist by the Irish psychiatrist Maurice O'Connor Drury more than 30 years ago. ${ }^{3}$ Van Helmont 'performed a certain experiment with great care and accuracy, whose result seemed irrefutable and yet at the same time absurd':

'He weighed accurately a certain quantity of earth and placing it in a large pot, planted a small ash sapling. Every day he watered the plant with pure distilled water, and in between these waterings he kept the surface of the soil covered so that no foreign extraneous matter should fall on it. In due time the sapling grew to such a size that its weight had increased more than a hundredfold, in fact it had become too big for the pot to hold it.
Van Helmont weighed it carefully, and then weighed the original soil he had filled the pot with, finding that this latter had lost nothing. He argued that therefore as the only additions made were those of pure water, all the materials in the tree, bark, pith, leaves, etc, were in some way composed of nothing but water. ${ }^{\text {3 }}$

Van Helmont's problem was that he knew nothing about the chemical processes, such as photosynthesis, at work in the plant that enabled it to grow. For O'Connor Drury, the point was that 'in the early stages of any science when there are still a host of unknown factors at work it can be most misleading to draw conclusions from experiments however accurately performed'. As he observed in relation to early randomised controlled trials in psychiatry, 'the methods employed may be too precise for the data on which they have to work'. In his view there were 'too many unknowns' in psychiatry for these methods to be 'either safe or applicable'.

For Lord Layard and his fellow campaigners, the term 'evidencebased' is a mantra that they chant to claim scientific authority for their grandiose schemes for 'state-of-the-art' primary care services. But the notion that an army of rapidly-trained barefoot psychotherapists can cure unhappiness by talk is a pipe dream that unfortunately distracts attention from the real problems of mental illness.

\section{REFERENCES}

1. Mind. For better mental health. We need to talk. Campaign for psychological therapies. http://www.mind.org.uk/campaigns_and_issues /we_need_to_talk (accessed 12 Apr 2010).

2. Professor Lord Richard Layard, A campaign for psychological therapies: the case.

http://www.mind.org.uk/assets/0000/7445/lord_ layard_document_new.pdf (accessed $12 \mathrm{Apr}$ 2010).

3. Drury M O'C. The danger of words and writings on Wittgenstein. Bristol: Thoemmes Press, 1976.

DOI: 10.3399/bjgp10X501994 